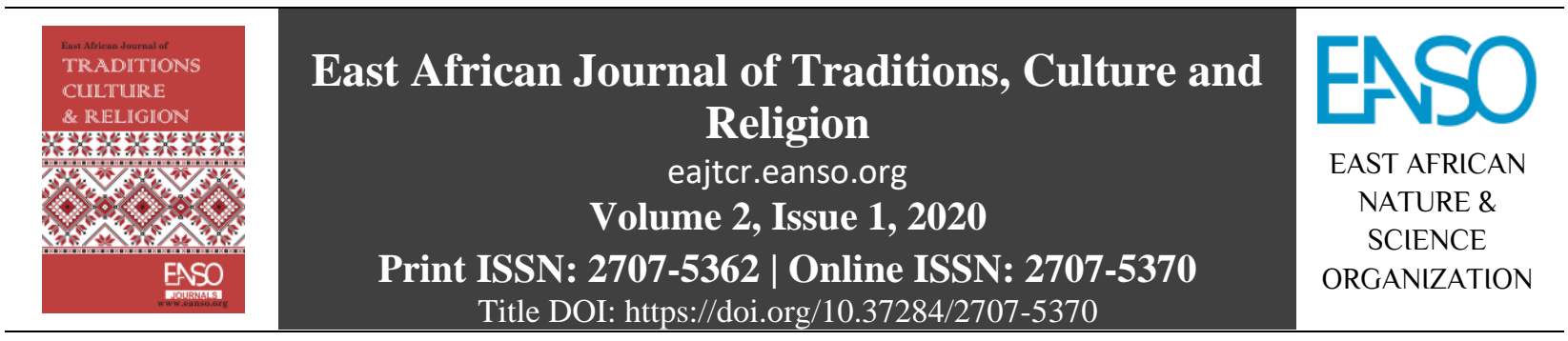

Original Article

\title{
Rethinking Religion and Sustainable Development in Africa
}

\author{
Dr. Prisca A. Gobo ${ }^{1 *}$
}

${ }^{1}$ Department of History and Diplomatic Studies, University of Port Harcourt, Nigeria.

* Author for Correspondence Email: drpriscaabiye1@gmail.com.

Article DOI: https://doi.org/10.37284/eajtcr.2.1.219

Date Published:

02 October 2020

\section{ABSTRACT}

This article suggests religion as a viable option for sustainable development in

Keywords: Africa. The focus will be on the three major religions in Africa, namely, African Traditional Religion (ATR), Islam and Christianity. The crux of this paper is on the areas of strength and similarities in the three religions which could foster development. Approaching this topic from within the African and African diasporic context, the nexus between the religions will be established. We will be historical in our interrogation of facts. By analysing the different historical sources and adherents of these religions, proper interpretation would be given to this topic using the interdisciplinary approach to historical writing. Conclusions would be drawn after careful examination of the facts which would clearly indicate that religion could aid sustainable development in more ways than one.

\section{APA CITATION}

Gobo, P. (2020). Rethinking Religion and Sustainable Development in Africa. East African Journal of Traditions, Culture and Religion, 2(1), 60-71. https://doi.org/10.37284/eajtcr.2.1.219

\section{CHICAGO CITATION}

Gobo, Prisca. 2020. "Rethinking Religion and Sustainable Development in Africa". East African Journal of Traditions, Culture and Religion 2 (1), 60-71. https://doi.org/10.37284/eajtcr.2.1.219.

\section{HARVARD CITATION}

Gobo, P. (2020) "Rethinking Religion and Sustainable Development in Africa", East African Journal of Traditions, Culture and Religion, 2(1), pp. 60-71. doi: 10.37284/eajtcr.2.1.219.

\section{IEEE CITATION}

P. Gobo, "Rethinking Religion and Sustainable Development in Africa", EAJTCR, vol. 2, no. 1, pp. 60-71 Oct. 2020.

\section{MLA CITATION}

Gobo, Prisca. "Rethinking Religion and Sustainable Development in Africa." East African Journal of Traditions, Culture and Religion, Vol. 2, no. 1, Oct. 2020, pp. 60-71, doi:10.37284/eajtcr.2.1.219. 


\section{INTRODUCTION}

Religion can be a major source of development or at least a major contributor to sustainable development in Africa in the twenty-first century. Having said that, in spite of the laudable involvement in promoting progress and development, religion in Africa has in some ways been inhibiting peace and progress. For instance, many atrocities are committed in the society in the name of religion such as religious extremism, religious intolerance, hypocrisy, fanatism, manipulation, extortion and exploitation, just to name a few. However, the argument here is that if religion is properly channelled, we would see more of the positive and less of the negative results. It is important to note that not all religious leaders and followers are guilty of such misconduct and crimes against humanity, but it is imperative that those who are culpable desist from such acts. The African society seems to be a society that victimizes the victim, the religious leaders and followers should not make it worse by exploiting the poor. If religious bodies and leaders focus more on promoting positive aspects of religion, it could become a viable tool for conflict resolution, peacebuilding and ultimately, unity and development. Religion may not completely rid the society of all the ills and social vices, but it would definitely reduce them to the barest minimum needed for growth and development. The emphasis here is not on which religion or faith is right or wrong, but simply to acknowledge religion as the bedrock for social, political and economic developmental strides in the African continent based on historical facts.

Unity is not uniformity. What is needed for positive change is the unity of purpose, not uniformity, and religion if properly harnessed, can provide that. This article is a contribution to the sustainable development debate. In an effort to boost the economy of African nations, there is a need to look inwards at what is already available - religion as a way of aiding the process of growth and ultimately development, in a sustainable manner.

\section{DEFINITIONS AND CLARIFICATION OF CONCEPTS}

\section{Religion}

The English Dictionary defines religion as the belief in a reality beyond what is perceptible by the senses and the practices associated with this belief. In the words of Onyeso (1989), religion is an instrument, a weapon in man's struggle to conquer or contain his primordial fear-fear of the present, fear of the future, and fear of life after death. Indeed, religion is as old as human society and rooted in history. The people of Africa were intensely religious even before the contact with Europeans. They regarded religion as the basis of reconciliation of the individual, families, clans and whole nations to the universe (Uya, 1992). Contrary to popular notions, the African believed in the existence of a great God long before the advent of Islam and Christianity. Among the Igbo, Yoruba, Efik/Ibibio/Annang of Nigeria and the Akan of Ghana, for example, God was known as Chukwu, Olorun, Abasi, and Onyama respectively. It is not possible to have a word for something that does not exist. The African Traditional Religion (ATR) comprises belief in God, belief in the divinities, spirits, ancestors as well as the practice of magic and medicine (Abia in Amadi et al., 2005). In ATR, God was accessible through a number of intermediaries, or messengers and "lesser gods." Religion is the thread that runs through every facet of the African life and is at the root of its value system, customs and traditions. Therefore, any development plan in Africa that does not take religion into consideration is an exercise in futility considering that religion is rooted in African history.

\section{Sustainable Development}

The 2030 Agenda for Sustainable Development, adopted by all United Nations Member States in 2015, provides a blueprint for peace and prosperity for the people and the planet in the present and the future. They adopted 17 sustainable development goals (SDGs) to be acted on by developed and developing nations alike. These 17 SDGs include: no poverty, zero hunger, good health and wellbeing, quality education, gender equality, clean water and sanitation; others are affordable and 
clean energy, decent work and economic growth, industry, innovation and infrastructure, reduced inequalities, sustainable cities and communities, responsible consumption and production, climate action, life below water, life on land, peace, justice and strong institutions and partnerships for the goals. These laudable goals can be achieved in Africa at least to a reasonable extent if African leaders and development planners will take into cognizance the important role that religion plays in the continent and if religious leaders and followers will indeed act like partners in development. African leaders have failed the continent so far, the religious leaders could change this narrative by using their leadership positions for nation-building in line with the dictates of their religion.

\section{Development}

Development could mean different things to different people. However, the English dictionary defines development as the process of developing; growth directed change. It is also the application of new ideas to practical problems. Development means "improvement in a country's economic and social conditions." More specifically, it refers to improvements in the way of managing an area's natural and human resources in order to create wealth and improve people's lives.

\section{THE NEGATIVE PRACTICE OF RELIGION IN AFRICA TODAY}

We are now prepared to undertake a systematic analysis of some of the major issues presented in the preceding sections, aggregating them and testing their implications on the African continent to aid development. African leaders have failed the African continent and its people. In the words of Chinua Achebe (1983), the trouble with Nigeria is simply and squarely a failure of leadership. This is true for all African nations. However, since nations rise and fall on leadership, the leadership of the religious sphere of the society is inclusive. There is a need to change our mindset and value system or else the society will self -destruct. The leadership of the three major religions needs to show exemplary leadership so that the circular leaders and the worshippers will follow their example. They have to show selflessness and initiative in the development agenda.
Rather, what is happening is that many religious leaders preach instant wealth by making their members, believers and followers believe that one can go to bed a pauper and wake up with duplexes and exotic cars just by "praying" and "sowing seeds." That same quick-fix mentality runs through every facet of African society. It is the driving force behind drug trafficking, advance fee fraud (419), cybercrime, armed robbery, bribery and corruption, kidnapping and embezzlement of public funds, the list is endless. Many now believe that all they need to succeed in life is a supernatural occurrence which will happen like a bang. This mindset is what Chinua Achebe calls the "Cargo-cult mentality" (Achebe, 1953). Unfortunately, the Nollywood industry is also guilty of promoting this negative stereotype through movies, further intensifying the damage considering its overwhelming influence on the populace. Imagery is a powerful tool that shapes the mindset and Nollywood being the mirror of the society seems to be unaware of the effects of its negative narrative on the African people and continent.

So on all fronts, the continent has been reduced to a continent of men and women who are eager to reap from where they did not sow, a people who do not work but want to eat, a people that believe more in good luck than hard work, a people that believe its duties and responsibilities will be carried out by supernatural forces one bright sunny morning and all its challenges will be over.

Therefore, whether the African nations prepare well for sporting activities like the Olympics, Common Wealth Games, Nations Cup, and World Cup or not, we hope and pray that we will win somehow. Whether or not the health sector, education sector, the agricultural sector and even governance is nosediving, it is believed that something will happen to turn around the fortunes of the nations and continent without a deliberate plan of action to make that happen. Africans have ignored the biblical injunction that "he who does not work should not eat and that faith without works is dead" (James 2:14-26). Maybe sowing of seed is seen as work these days. Seeing the desperation of the people to make quick money and have major breakthroughs in every area of life, some conmen in the name of religious leaders simply feed on their desperation, insecurities, frustration, poverty, fears 
and weaknesses by making them believe that some rituals or prayers can give them the desired result overnight. And these rituals and prayers usually cost a lot of money which makes the poor poorer and the rich richer. Consequently, widening the gap between the haves and the have-nots.

The major paradox in the African society is that it seems the more the proliferation of Churches, Mosques and ATR worship centres, the worse we become morally. Social vices like corruption, violence, criminality, poor work ethic, low productivity, poor governance, poverty, killing, kidnapping and dishonesty are on the increase just as the worship centres are increasing. In fact, the people are now killing and stealing in the name of religion so much so that many are beginning to question the impact of religion on the moral tone of the people. In comparison, atheistic nations like Japan, China and Australia are doing better morally and making giant strides in development than Africa where most of the people are religious (Ohuabunwa, 2018).

The reason (though not an excuse) is that prolonged poor governance in Africa has created so much poverty in the land that the religion most people understand now is the religion of "stomach infrastructure" whereby many worship any god that will guarantee regular meals. The religious leaders are only interested in "tithes and offerings" and not the salvation of souls. To the religious leaders, religion is now a lucrative business. Poverty and high unemployment rate made a lot of people desperate to the point of turning religion into a business venture. And since some of the people are so gullible and insecure, they are searching for God in all the wrong places and holding on to anything and anyone that pretends to proffer solution. So, the people in their search for food and God are tricked into giving out the little resources they have in the hope of getting more, thereby enriching the religious leaders at the expense of the poor majority. The religious leaders are using religion for personal aggrandizement in a situation that could be likened to modern-day religious slavery. Poverty has been weaponized by both the religious leaders and the circular leaders and the poor masses continue to get poorer while the leaders get richer. This practice hampers development and in some cases destroys developmental projects and can precipitate the decline of nations (Olarinwoye, 2011). This is a dysfunctional system but it is a system nonetheless. Unless and until we sanitize the system and make it functional, no real development will take place. Sometimes, conflicting beliefs and values of these religions may even be counterproductive. Such beliefs include family planning, use of contraceptives, blood transfusion, HIV/AIDS prevention and caesarean section among others. These beliefs and practices have to be re-evaluated in line with the development agenda.

\section{Harmonising the Three Religions for Development}

Nevertheless, religion should encourage the development of the African continent through its many worshippers and practitioners. Thus, Tamuno rightly stated that peace is second to none as a necessary ingredient for orderly development politically, socially, economically, religiously, culturally and otherwise. Tamuno, therefore, recommended three things as a prerequisite for development: Education; more education; and yet more education (Tamuno, 1991). In this case, education in religion and African history could very well be the Panacea for this misconception and misrepresentation of religion and culture by our religious leaders. The religious priests and leaders need a proper education of the religions they claim to represent to clarify the fact that they do actually have more in common than they realized and these can be explored and harnessed for the greater good of Africa and humanity. The religious leaders need to stop misinterpreting and misrepresenting the religions they represent. The three religions preach peace (Christianity, Islam and ATR), that could be a starting point. Peace is a prerequisite for development.

In the words of Balogun (1956:61), each of these religions has norms and values which are similar and which if sincerely observed would nurture and strengthen the nation. Some of these norms include the concept of reward and punishment, accountability before the Supreme Being, the concept of life after death, and judgement which are meant to discourage criminality in the society and encourage good and orderly conduct among people. The common religious values also include justice, 
peace, love, tolerance, respect for human life, and obedience to laws of the land, just to name a few.

Religions in Africa conform to the idea of justice. For instance, the Muslims set up Sharia Courts and the Christians swear with the Bible in the court of law and also have Biblical injunctions that encourage justice. The ATRs also have their own judicial systems and ways of administering justice which is mostly done by swearing by the deities of justice (Ojoajogwu, 2014). They just have to find a way to harmonize their practices without infringing on the rights of each other to achieve the desired goal of peace and development.

Agreement on core values results in less conflict and more unity. The emphasis here is on unity, not uniformity. The family unit in Islam is considered responsible for the emotional well-being, security and personal sense of worth for its members (Kilani, cited in Ugiomoh et al., 2017). And when the family is whole and united it spreads to the wider society. Similarly, in Christianity, the family unit is seen as sacred and a unifying factor that is why the first miracle Jesus performed was at a marriage ceremony in Cana of Galilee (John 2:111) to emphasize the significance of the family. The ATRs have always had the family unit as a symbol of unity and relevance in the society, hence, the continuous intervention and resolution of family conflicts. Like all other family institutions all over the world, the African family institution has been impacted by modernization, secularization and globalization adversely. However, the family still remains the primary unit of human interaction in society.

Globalization and its consequences have signalled a deterioration of moral standards, decline of religious scruples and a cultural breakdown (Kilani, cited in Ugiomoh et al., 2017) which are reflected in the family unit and the wider society. However, for the fact that all three religions recognize the undeniable fact that family cohesion and development of the society are paramount, there is need for homegrown solutions tailored to suit the needs of the contemporary African families and society. The importance of the family unit in the overall scheme of things cannot be overemphasized. The fundamental religious role of the family is to create a human environment conducive to spiritual and moral education for selfimprovement and for both individual and collective success for the society. If more families in a nation are dysfunctional, the nation will be dysfunctional. That is why the solidarity of the family and strength of the family ties is paramount in Islam, Christianity and ATRs (Ugiomoh et al., 2017). In traditional African cultures, marriage, childbearing and family obligations are religious duties. Religious traditions reinforce the idea that family members must be responsible for each other. The youths must care for the elderly, children must obey their parents and elders, and parents must teach, provide and care for their children. This is also covered by the Bible and the Koran.

A survey of people's religious beliefs carried out in ten countries in 2004 by British Broadcasting Corporation (BBC News, 2004) showed that Nigeria was the most religious nation in the world, topping the list by ninety per cent of the population opting for their religious beliefs as a moral guide to life. This passion for religion in Nigeria could be useful in social cohesion considering the fact that it is the most populous African nation and wields a lot of influence on the African continent. But that is only possible if the people actually put into practice what they believe.

This religiosity can be utilized for the development of the country through the nurturing of human conscience for honesty and transparency. (Adebayo 2012). Although there are many factors inhibiting the contribution of religion to development in Africa, it is still an important factor for sustainable development (Ogbonnaya, 2012). Africa has to begin to make the most of all they do have instead of focusing all their energies on oil, diamond, gold and other natural resources only. All the human and natural resources including religiosity should count for something in the overall scheme of things if Africa is sincere and serious enough about sustainable development. After all, even nations who are not religious are making giant strides in development.

For indigenous Africans, history usually refers to accounts of events as narrated in stories, myths, legends and songs. The ATRs also follow the same pattern. Myth and oral history are integral elements of their cultures. Such history has been confirmed 
to be as reliable as the written accounts of the developed nations through archaeological excavations, radiocarbon dating and DNA sampling.

Furthermore, ATRs have creatively responded to this religious onslaught by formulating new ways of documenting their religious code of conduct like the written forms of the Bible and Koran. They have done this by developing literature, institutionalizing the traditions and training priests. This is development. Despite the efforts made by ATRs to adopt written forms, the oral forms are still respected and valued. Among many African ethnic groups, some sets of oral narratives exist which serve as sacred texts and the faithful who transmit this knowledge are considered sacred.

A classic example is Ifa divination which is popular among the Yoruba of South Eastern Nigeria. There is hardly a topic or issue that Ifa fails to address. Oral narratives define morals and values for traditional religions just as written texts do for religions that have sacred books. During their long periods of apprenticeship, diviners memorize Ifa verses which may be as long as 256 Ode. The message and sacrifices contained in Ifa verses are a genre of oral tradition which preserves the Yoruba religious worldview through myths, proverbs, songs and poetry.

Ancestors, demigods and spirits are intermediaries between deities and humans in the ATRs. Similarly, Jesus Christ is the intermediary between God and the Christians and Mohammed is the intermediary for the Muslims. All three religions believe in an intermediary to reach God. The Ancestors in African tradition were usually men of valour and integrity emphasizing the importance of living an exemplary life for posterity just as Jesus is the example for Christians and Mohammed for the Muslims. For instance, in ATR while pouring libation, a clear distinction is made between the good ancestors whose names are generally recited with the cup of wine in the right hand, and the bad ones who are remembered with the cup in the left hand (Uya, 1992). In this manner, ATR encouraged good and upright behaviour.

Furthermore, every African community and ethnic group has its own religious place of worship like Temples, Shrines and alters which are located all over the continent. They also have natural religious sites like forests, rivers, lakes, trees, mountains, waterfalls and rocks which were chosen based on historical or special events. These places are as sacred to them as Jerusalem, Mecca, Churches and Mosques are to Muslims and Christians. What is needed is religious tolerance and respect for one another. Even if they need to evangelize and get converts to a particular religion, it does not have to be violent if they genuinely want development.

The sense of community spirit is deeply rooted in African traditional values of mutual respect for one another and progress of the society. The values of the community are encoded and communicated in speech forms, myths, proverbs, songs and titles. Such expressions as Igwe-bu-ike (in number there is strength), nnadi-ka (the kin group is supreme) underpin Ikwerre indigenous sense of community South East of Nigeria. (Ugiomoh et al., 2017). And still in South-East Nigeria, in Okrika, they usually say, mina iyoen (meaning there is strength in family or relatives). What this means is that responsibility is shared.

Moreover, they share responsibility in the education and training of children. This finds expression in the popular African saying that $a$ child does not belong to one man or it takes a village to raise a child. Reciprocal arrangements during the planting and harvesting seasons or in the building of a new house are common in African traditional belief. Similar to the brotherly love preached in the Bible and Koran. There is need to focus on these areas of unity for the purpose of development.

In this manner, religion can serve as a springboard for the inculcation and improvement of ethical values which are fundamental to achieving proper human conduct especially as it relates to productivity and nation-building (Ojoajogwu, 2014). It has been observed that the three major religions in Africa have similarities in their ethical code and this is an encouragement and a possible impetus for the quest towards inter-religious harmony (Ojoajogwu, 2014).

In addition, the relationship between the living, dead and unborn in African societies is deeply rooted in African traditional religion (Mbiti, 1969) and this is also emphasized in Christianity and 
Islam which emphasizes the importance of history, legacy and continuity. The responsibility of caring for one's children and guiding them aright is integral to the drive for legacy. The drive for legacy inspires men and women to do great works and noble actions (Wariboko, 2007).

The centrality of community life is integral to Africans. All reconciliation methods in the African society reflect the underlying African understanding of life as relational or communitarian (Ijezie cited in Ugiomoh et al., 2017). Reconciliation, therefore, involves mending the breaches that result in any of the links between fellow humans, the land and spirits/deities. Many traditional methods of reconciliation achieved results and because of this many people of other faiths are clamouring for the revival of such methods to checkmate crime and criminality in the society today.

This partly explains why many people in Africa, though converted to Islam and Christianity still practice their African traditional religion secretly especially when faced with serious challenges. Many indulge in acts of dual allegiance. Sometimes one's loyalty to Christian principles often enters into conflict with the community principles. But ignoring the community pressure in favour of the Christian principles is tantamount to social ostracism. (Ijezie cited in Ugiomoh et al., 2017). A healthy balance between the traditional and the contemporary is, therefore, necessary for development.

That Africans are a deeply religious people is a fact already stated. However, this religiosity is very worldly and based on utilitarian rather than spiritual or mystical (Mbiti, 1969). This is well captured in the prosperity gospel of contemporary evangelism and Pentecostal Churches. And it is not unconnected to the colonial legacy whereby the missionaries lured converts with material things such as schools and hospitals which are good in themselves but later misunderstood and abused. A genuine conversion that embraces selflessness is urgently needed for societal growth.

The conflict between faith and culture plays out in different forms and it's a contributory factor to superficial faith and underdevelopment in Africa. The Christian faith, for instance, has to recognize the intrinsic values of the African culture, while the African culture has to open itself to further renewal and purification by the faith (Ijezie in Ugiomoh et al., 2017).

After all, knowledge and even religion are dynamic. It is necessary to make the African Christian truly African and truly Christian. Islam, on the other hand, is said to be successful partially because of its continued tolerance of traditional African beliefs and practices or its compatibility, therefore it should aid development in the African continent. Religion is the core of culture (Shorter, 1973). This is why men need religion to provide them with a framework of thought and symbolism that will help them to integrate into society (Shorter, 1973). Africans find it difficult to discard their past because religion (ATR) is at the heart of their core values. African primal religious views are similar to those found in the Bible (Oduyoye, 1986). Therefore, it will be foolish to disclaim them. Mbefo (1989) blames the mission Churches for insisting that Africans should abandon contacts with their traditional religion and cultures which has created confusion.

The African believes that witchcraft, illness, misfortune, tragedy and death are the manipulations of malevolent spirits and so he spends his entire life trying to appease the spiritual beings like the ancestors, divinities and God to achieve success. To further buttress this point, Anderson (2004) posits that in times of crisis, most Africans no matter their new religion visit prophets, diviners, and seers, who are believed to have deeper perceptions of the spiritual realm and can thus help achieve cosmological balance. Nothing explains the fusion and the need to find harmony in the three religions for the purpose of development better than this. The harmony is already happening unconsciously, what is needed is to make it a conscious and deliberate policy by all stakeholders.

\section{AFRICANIZATION OF RELIGION}

In a bid to make religion relatable to the people, the African church is making an effort to Africanize the Church by setting up different sections of the Church. For instance, most Churches have deliverance ministries and programmes for their members and prayer for the sick are offered 
regularly. There are also counselling sections, Youth Fellowship, Women's group, Men's group and Singles Fellowship all tailored to meet the needs of the African Christian. They now see God talking to their situations and meeting their specific needs. Thus far, the theology of contextualization has begun and this should put them in the right frame of mind to engage in their productive ventures.

This call for an effective contextualization of foreign religions in Africa is imperative because the people still straddle between the indigenous religion and foreign religions. It simply means that even the centuries of slave trade and separation from the continent could not stop it. This is because the African indigenous religious heritage is the substrate of their cultural and social consciousness (Gbule cited in Ugiomoh et al., 2017). Actually, an important aspect of African cosmology and worldview is an openness to ideas and adaptation of other religions' cultural traditions, tolerance of religious differences, a commitment to change, creativity and elaboration of new traditions without necessarily destroying the old, (Uya, 1992). New gods were accepted and integrated into the existing pantheons. The gods of the conquerors were particularly attractive to the vanquished. It is in this context that the acceptance of Christianity and Islam by Africans should be understood (Uya, 1992). And I dare to say that it is also in this context that the practice of ATR behind closed doors even after accepting Islam or Christianity should be viewed.

Africans are deeply spiritual people to the extent that Christianity and Islam have become Africanized on the continent. This has significantly changed the practice of the two religions and produced a distinct African expression of them. The Church in Africa over time has responded with various missionary and theological models such as adaptation, incarnation, contextualization and lately, inculturation, all aimed at recognizing the identity of the local cultures (Ijezie cited in Ugiomoh et al., 2017).

This became necessary also because a crisis of identity was created in Africa as African Indigenous sources of knowledge are steadily replaced by global values dictated by foreign cultures and religion. It is important that religion in Africa is practised in such a way that it brings development. Islam is defined not only as a religion with laws guiding values, rituals, human transactions and morals but as a way of life (Kilani cited in Ugiomoh et al., 2017) just like Christianity and ATR. There are religious regulations guiding politics, economy and culture which if adhered to sincerely will enhance the peaceful development of the society.

Nigeria is said to have the highest number of Churches in the world. There are more Mosques in Nigeria than anywhere else in the world. The ATR is not left out because there are shrines and covens in every hamlet for traditional worshippers (Ohuabunwa, 2018). This high regard for religion that is so well expressed and established can create the right mindset and atmosphere for peace and progress in Nigeria and by extension Africa if the religious leaders and followers alike will practice what is preached.

\section{The African Diasporic Context of Religion}

The African Traditional Religion is so alive that it has spread to the Diaspora and is influencing global cultures. From the fifteenth century to the nineteenth century, the transatlantic slave trade took African religions to the Americas and the Caribbean. Contact with Catholicism in Brazil, Cuba and Haiti produced new forms of religious syncretism called Candomble, Santeria and Vodum. And this religion of African immigrants has influenced American culture. There are a number of West African Babalawos (diviners) practising in major American cities like Atlanta, Miami and New York City. It is significant to note that the most ardent practitioners of Orisha worship (of the Yoruba of Nigeria) in Argentina and Uruguay are white rather than Afro (Uya 1992).

In Brazil, Iya Orisha Rauda de Osun, a virgin at 81 years old, a priestess, presides over the Osun and Orisa shrines in Brasilia, the capital of Brazil. She built shrines and altars that house the spirits of Orisa, Ogun, Sango, Obatala and Esu (all gods of the Yoruba of Nigeria) (Mangut \& Wuam, 2012). The Orisha house is surrounded by thick forests on both sides and it has become one of the major tourist centres in Brazil (Udeze, 2009). 
The Africans in the Diaspora, though taken there under the most inhuman circumstances, took their religious practices with them to the Americas, the Caribbean and wherever they found themselves. They introduced enduring forms of African religious culture through music, dance, festivals and martial arts. This is most common in Brazil, Peru, Cuba, Trinidad, and other places with large African populations. With the spread to different locations in the diaspora, new forms of these ATRs emerged to cater to the spiritual needs of the people. This is a development that cuts across the African continent to the diaspora.

Although a huge number of Africans have converted to Islam and Christianity, these two world religions have been assimilated into African cultures, and many of them though converted to Christianity or Islam still maintain their traditional spiritual beliefs. This cuts across regions and space in the African continent. Other West African cultures have similar creation myths and social traditions, which is proof of the dynamism of these traditions and influence between cultures. The Fon of Benin, in Western Africa and the Yoruba of Nigeria share many elements of a highly intricate cosmology.

They have many deities in common like Sango, the god of thunder and lightning, Ogun, the god of war and Iron, Esu, the messenger of the gods, and Ifa, the god of divination. Members of the Mwari cult in Zimbabwe (West Africa) and Botswana (East Africa) usually engage specifically in rituals intended to influence the economy and maintain environmental balance. The fact that even centuries of Trans-Atlantic Slave trade and colonialism could not obliterate the religious belief of the people of Africa in time and space is a clear indication of its resourcefulness in development.

\section{RELIGION AND DEVELOPMENT}

Religion in Africa has played more positive roles in the growth and development of the continent than the negative practices. Religion has helped the growth and development of Africa. Early education in Africa was influenced by both Christian and Islamic religions. Most of the mission schools in Africa and health centres were established by the missionaries (Sanne, 2013). Even though the aim was to attract converts, they became beneficial to society at large.

Hitherto, development studies paid no attention to religion and that is an irony because development embodies similar values with religion. In fact, development becomes a sort of faith per se (Crush, 1995), a very well-defined system of beliefs with its own ethics, trajectories, rituals, leaders and rewards and holy places. Furthermore, Sanne (2003) still insists that the churches were the only viable structure remaining after the breakdown of state institutions, and as such had to shoulder a disproportionate burden of the problems of their societies, especially in the area of education and health care which are crucial sectors of human development. Religious based charitable contributions have been a major source of welfare and religious organisations have been the most important non-state providers of basic human necessities to the needy in Africa. Faith-Based Organisations (FBOs) increased as a result of economic neo-liberalism as the faithful responded to growing poverty, inequality and social exclusion (Bompani, 2011). Instead of decreasing, religion is taking an increasingly central role in African political and developmental life (Deneulin \& Bano, 2009; Ter Haar \& Ellis, 2006). According to a World Bank Report, 50\% of health care and education services in Sub-Saharan Africa in 2000 were provided by faith-based organisations (World Bank, 2008). The Evangelical Development Agency World Vision had an effective aid budget of $\$ 1.25$ billion in 2002 (World Vision International, 2003). The World Bank pointed out that in Benin, the church represents 'the most prominent and effective protection network' (Kliksberg, 2003). In South Africa, the church is also making a significant contribution to growth and development. The Catholic Church was providing more anti-retroviral treatment for HIV/AIDS patients than the state until very recently. The church in South Africa also plays significant roles in agricultural extension and influencing of policies. It is believed that the annual budget of the Christian Service Committee of the churches of Malawi which was a key ecumenical organisation, was 1.5 times the size of the state's total development budget (World Faiths Development Dialogue, 2003). A number of religious organisations have been compelled by 
circumstances in Africa to provide development (Tyndale, 2006; Marshal \& Van Saanen, 2007). There are other well-established religious development organisations like CARITAS, SCIAF, CAFOD, World Vision, Islamic Relief, Aid for Africa, Ghanian Mother's Hope, Uganda Christian University Partners, and World Hope International, just to name a few. The Christian Association of Nigeria (CAN) and the Nigerian Supreme Council for Islamic Affairs (NSCIA) contribute in many ways to the sustainable development of Nigeria (Olarinwoye, 2011).

The Federation of Muslim Women Association of Nigeria (FOMWAN) with consultative status in the United Nations aims at the intellectual and economic empowerment of Muslim Women, the rehabilitation of children and orphan centres, the encouragement of young girls to embrace education and proper and adequate health care (Olarinwoye, 2011). This is done in partnership with the Nigerian Programme of Nomadic Education Programmes. Sheikh Salim tells us that after the holy month of fasting, Muslims are encouraged to make free-will donations to the poor. He further stated that "we have trained Imams and the young boys about Gender-based violence (GBV) and how to respect women and now they are passing on the information'. Islamic leaders played an important role in the fight against polio (Yahya, 2007). Islamic Relief is an international aid agency founded by Hany El-Banna in 1984 to provide humanitarian relief and development programmes in over forty countries. The organization provides for communities in need regardless of race, political affiliation, gender or belief. Through this agency, 7.4 million people have benefitted from their emergency and development programmes. In 2017, $£ 5.3$ million was given out as a loan to improve lives through Islamic microfinance banks. Furthermore, the agency has sponsored 56 projects to reduce the impact of climate change.

A FBO under the General Overseer of the Omega Power Ministry, Apostle Chibuzor Chinyere built the first free hospital in Nigeria cited in Port Harcourt, Rivers State to offer free treatment to the people, he gives free education and scholarships to undergraduate and postgraduate students to study at home and abroad, he gives free foodstuff, free restaurants, free accommodation and even free Skill
Acquisition Centres for all irrespective of their religion in Rivers State, Nigeria, and beyond. Religious leaders in Africa have been very active in the fight against Covid-19 pandemic. They have done this by creating awareness, addressing genderbased violence (GBV-which has been on the increase as a result of the victims being in lockdown with their abusers), giving palliatives such as foodstuff and cash donations to the most vulnerable in the society. In many African countries, FaithBased Organizations provide between 30\% - 70\% of health care services. The World Bank Group revived its engagement with Faith-based and religious organisations in January 2014 on the realization of the fact that they are often doing the essential work of fighting poverty and providing welfare services.

In Uganda, Pentecostal-Charismatic Churches are active in the media contributing to national debates about morality, human rights and security, and influencing policy decisions. Although not institutionalized like Christianity and Islam, ATRs provide a sense of security and assurance of assistance from the spirit of the ancestors which Africans believe serves as a protective shield against evil forces such as witches and wizards capable of disrupting individual and communal development (Ogbonnaya, 2012). This puts them in the right frame of mind to engage in their productive activities. When faced with daunting challenges, the majority of African Christians and Muslims still resort to ATRs to find solutions and success which keeps them going. In fact, religion provides emotional stability for believers. Emotional stability that gives them a positive attitude and energizes them to generate wealth. By seeking to proffer answers to perplexing questions of man's existence in a world full of vicissitudes, religion is a sort of balm (Akinola in Layiwoola et al. 2008). Religion thus contributes to the stabilisation of society by enhancing the emotional and psychological equilibrium of its members (Akinola in Layiwola et al., 2008) which ensures productivity. Similarly, it strengthens the mores by which every community, through time-honoured customary practices, seeks to maintain peace and order. In spite of their laudable involvement in promoting progress and sustainable development, religions in Africa have in some ways been inhibiting sustainable development and these 
excesses can be checked by the Faith-Based Organizations (FBO). Vigilance and some sort of censorship by the major religious bodies like CAN and NCIA should expose the false prophets in their midst that is if they are not guilty of the same offences. Self-righteous hypocrisy will not produce the desired result, so the members of the FBOs have to be people of faith and integrity.

Some religious leaders are even known to collaborate with corrupt politicians to further their own personal agenda. Such practices must be checked. In spite of these shortcomings, religious bodies and organisations have been great partners in development through their grassroots development efforts in education, healthcare, social justice and climate change. These organisations create change by empowering the vulnerable and restoring hope and dignity to humanity.

\section{CONCLUSION}

The connections between religion and sustainable development cannot be overemphasized. The fact that the African is deeply religious is useful to society in terms of development. All that the people need is the right kind of religious leaders who would use their massive influence on the people to sway them in the right direction of godliness and unity of purpose. Considering the large audiences and followership under the influence of these religious leaders, all that is needed is for the leaders themselves to practice what they preach and the people, at least the majority will emulate them. Today, they bring comedians to churches because the modern-day church is now more of a social gathering, lacking spirituality. This is a huge distraction in worship centres and it defeats the purpose of the church in my opinion. There should be a time and place for everything so that there would be order in society. And order always creates productivity.

\section{RECOMMENDATIONS}

Religious leaders and bodies have direct access to the people and this should be fully utilized for the greater good, not for personal aggrandizement. While they are involved in national development through their Faith-Based Organizations (FBOs), religious leaders must fight corruption and injustice rather than promoting such vices directly or indirectly. Their influence in society must be used to promote the common good and sustainable development. Worship centres should be purposedriven and focused on spirituality and development of individuals and society.

\section{REFERENCES}

Achebe, C. (1984). The Trouble with Nigeria. Oxford: Heinemann Education Books.

Adebayo, D. (2012). The Paradox of High Growth and High Poverty in Nigeria. Retrieved from Spines Blog Spot, available at https://thespinesblogspot.com/2012/paradoxof-high-growth-high-poverty.

Amadi, I., Udoka, I., \& Ochefu, Y. (eds.) (2005). History and Citizenship: Essays in Honour of Okon Edet Uya. Calabar: University of Calabar Press.

Anderson, A. H. (2004). African Reformation: African Initiated Christianity in the $20^{\text {th }}$ Century. New Jersey: Africa World Press.

Balogun, M. J. (2002). The Democratization and Development Agenda and the African Civil Service: Issues Resolved or Matters Arising? International Review of Administrative Sciences, 68(4), 533-556.

BBC News. (2004, Feb 26). Nigeria leads in religious belief. Retrieved from BBC News, available

from http://news.bbc.co.uk/2/hi/programmes/ wtwtgod/3490490.stm.

Crush, J. (eds.) (1995). Power of Development. London: Routledge.

Deneulin, S. \& Bano, M. (2009). Religion in Development: Rewriting the Secular Spirit. London: Zed Books.

Ejizu, C. I.; Ugiomoh, F. A. O., Owete, K. I., \& Odili, J. U. (eds.) (2017). Religion and the Bounds of Culture: Festschrift in Honour of Professor Christopher Ifeanyichukwu Ejizu: Port Harcourt: Rock Publishers. 
Kliksberg, B. (2003). Facing the inequalities of development: some lessons from Judaism and Christianity. Development, 46(4), 57-63.

Layiwola, D., Albert O., Muller B. (eds.) (2008). The Contexts of Non-Linear History: Essays in Honour of Tekena Tamuno. Ibadan: Sefer Books Limited.

Mangut, J. \& Wuam, T. (eds.) (2012). Colonialism and the Transition to Modernity in Africa. Ibadan: Sam-Adex Printers.

Marshall, K. \& Van Saanen, M. (2007). Development and Faith: Where Mind, Heart and Soul Work Together. Washington D.C., The World Bank.

Mbefo, L. N. (1989). Towards a Mature African Christianity. Spiritan Publications.

Mbiti, J. S. (1969). African Religions and Philosophy. London: Heinemann.

Oduyoye, M. A. (1986). Hearing and knowing: Theological reflections on Christianity in Africa. Maryknoll. New York: Orbis Book.

Ogbonnaya, J. (2012). Religion and Sustainable Development in Africa: The Case of Nigeria. International Journal of African Catholicism, 3 (2), 1-22.

Ohuabunwa, M. S. I. (2018, Nov 20). Has Religion Promoted Development in Nigeria? Retrieved from Business day, available from https://businessday.ng/columnist/article/religio $\mathrm{n}$-promoted-development-nigeria/amp/.

Ojoajogwu, O. N. (2014). Religion as a catalyst of nation-building in Nigeria. Net Journal of Social Sciences, 2(2), 71-76.

Onyeso, N. (1989). The Political Economy of Religious Fundamentalism in Nigeria. Department of History, University of Calabar.

Shorter, A. (1973). African Culture and the Christian Church. London: Geoffrey Chapman.

Ter Haar, G., \& Ellis, S. (2006). The role of religion in development: Towards a new relationship between the European Union and Africa. The European journal of development research, 18(3), 351-367.

Tyndale, W. (Ed.). (2006). Visions of development: faith-based initiatives. Ashgate Publishing, Ltd.

Uya, O. E. (1992). African Diaspora and the Black Experience in New World Slavery. New Rochelle: Third Press.

Wariboko, N. (2007). Pattern of Institutions in the Niger Delta: Economic and Ethnological Interpretations of History and Culture. Port Harcourt: Onyoma Research Publications.

World Bank. (2008). The World Bank's Commitment to HIV/AIDS in Africa: Our Agenda for Action, 2007 - 2011. Washington, D.C.: The World Bank.

World Faiths Development Dialogue. (2003). The Provision of Services for Poor People: A Contribution to WDR 2004. World Faiths Development Dialogue.

World Vision International. (2003). Annual Report. Retrieved from: http://www.worldvision.com.au/aboutus/cooperative-governance/annualreports.aspx.

Yahya, M. (2007). Polio vaccines - "no thank you!" barriers to polio eradication in Northern Nigeria. African Affairs, 106(423), 185-204. 